\title{
Response of Integrated Nutrient Management on Yield and Economics of Rice (Oryza sativa L.)
}

\author{
Vishnu $^{1}$, Vishal Verma ${ }^{2 *}$, Gabu Singh Gathiye ${ }^{3}$, Anil Kumar ${ }^{4}$ and Shri Rakesh ${ }^{5}$ \\ ${ }^{1}$ Department of Agronomy, College of Agriculture, Jawaharlal Nehru Krishi Vishwa \\ Vidyalaya, Jabalpur Madhya Pradesh-482004, India \\ ${ }^{2}$ Division of Genetics \& Plant Propagation, Tropical Forest Research Institute, \\ Jabalpur, Madhya Pradesh-482021, India \\ ${ }^{3}$ RVSKVV- Krishi Vigyan Kendra, Dhar, Madhya Pradesh-454001, India \\ ${ }^{4}$ Department of Genetics \& Plant Breeding, ${ }^{5}$ Department of Agronomy, College of \\ Agriculture, Swami Keshwanand Rajasthan Agricultural University, Bikaner, \\ Rajasthan-334006, India \\ *Corresponding author
}

\section{A B S T R A C T}

\section{Keywords \\ NPK, \\ Vermicompost, Yield, Net returns and $\mathrm{B}: \mathrm{C}$ ratio \\ Article Info \\ Accepted: \\ 07 August 2020 Available Online: 10 September 2020}

\begin{abstract}
The field experiment was conducted at AICRP IFS Research Farm, Krishi Nagar, Jawaharlal Nehru Krishi Vishwa Vidyalaya, and Jabalpur (MP), India during kharif season of 2016. The results reveled that yield attributes viz., number of effective tillers/hill, length of panicle, number of grains/panicle, number of filled grains/panicle, number of unfilled grains/panicle, test weight and grain yield, straw yield and harvest index of rice were higher with application of $100 \%$ NPK through fertilizers as compared to $100 \% \mathrm{~N}$ through vermicompost, $75 \% \mathrm{~N}$ through vermicompost, farmers practice $\mathrm{N}: 60, \mathrm{P}: 30$ through fertilizers +3 tonne $\mathrm{FYM} / \mathrm{ha}$, $50 \% \mathrm{~N}$ through vermicompost $+50 \% \mathrm{NPK}$ through fertilizers, $75 \% \mathrm{~N}$ through vermicompost $+25 \%$ NPK through fertilizers and absolute control. Net returns (68749₹/ha) and B:C ratio (3.11) also maximum with application of $100 \%$ NPK through fertilizers.
\end{abstract}

\section{Introduction}

Rice (Oryza sativa L.) crop occupies the enviable prime place among the food crops cultivated around the world and remains as the most important staple food crop of the world (Krishnan et al., 2011). It is major source of calories for $40 \%$ of the world population. India is the second most populous nation and the largest producer of rice in the world after China. In India, rice is covered 43.79 million ha acreage and contributing 116.42 million tonnes grain production with productivity of $2659 \mathrm{~kg} / \mathrm{ha}$ (GOI, 2019). Cultivation of high yielding dwarf varieties high responsive to fertilizer and excess use of inorganic fertilizers has depleted the inherent soil fertility. Enhancing the rice productivity 
through the appropriate nutrient management has been the main thrust of Indian rice policy. The decline or stagnation in yield has been attributed to nutrient mining and reduced use of organics (John et al., 2001). Inorganic fertilizer is one of the key factors to increase the rice productivity. Rice yield and biomass increased rapidly due to increased use of chemical fertilizers. Several long-term experiments conducted all over India showed that a decrease in rice productivity due to continuous use of imbalanced chemical fertilizers. As a result, agricultural ecosystems remain in a state of chemical nutrient saturation, leading to huge nutrient losses through leaching, runoff, volatilization, emissions, immobilization and subsequent low nutrient use efficiency (Zang et al., 2012). Integrated nutrient management (INM) aims to improve soil health and sustain high level of productivity and production (Prasad et al., 1995). Singh and Kumar (2014) reported increased yield and nutrient use efficiency in rice with organics.

Organic supply of nutrients at the peak period of nutrient absorption also provide micro nutrients and modify soil-physical behavior as well as increase the efficiency of applied nutrients (Pandey et al., 2007). Vermicompost means a casting of earthworms. It is a prime source of organic recycling of organic wastes and a good source of macro and micro nutrients in chelated form and fulfills the balanced nutrient requirement of plants at longer period. Vermicompost also helps in reducing $\mathrm{C}: \mathrm{N}$ ratio and in increasing humus content of the soil and provide a wide range of nutrient in the readily available form to the plants, such as nitrate, soluble phosphorus exchangeable potassium, calcium, magnesium (Talashilkar et al., 1999). The integrated use of use of organic and inorganic fertilizers has been reported not only to meet the nutrients need of the crop but also has been fund to sustain large scale productivity goals (Yadav and Meena, 2014). In view of above fact study on integrated nutrient management was carried out for identifying most effective nutrient source and their optimum dose for harvesting higher yield of rice.

\section{Materials and Methods}

The field experiment was carried out at AICRP IFS Research Farm, Krishi Nagar, Jawaharlal Nehru Krishi Vishwa Vidyalaya, and Jabalpur (MP), India during kharif season of 2016. The soil of experimental field was sandy clay loam, neutral in reaction $(\mathrm{pH} 7.2)$ having $269.83 \mathrm{~kg} / \mathrm{ha}$ available $\mathrm{N}$ (Alkaline permanganate method (Subbiah and Asija, 1956), medium in available phosphorus (12.7 $\mathrm{kg} / \mathrm{ha}$, Olsen's method (Olsen et al., 1954 and medium in available potassium $(283.3 \mathrm{~kg} / \mathrm{ha}$, Flame photometric method (Metson, 1956) in $0-15 \mathrm{~cm}$ soil depth at the start of the experiment.

The experiment was laid out in randomized block design with three replications. There were seven nutrient management treatments viz. $100 \% \mathrm{~N}$ through vermicompost, $75 \% \mathrm{~N}$ through vermicompost, $100 \%$ NPK through fertilizers, farmers practice N:60, P:30 through fertilizers +3 tonne FYM/ha, $50 \% \mathrm{~N}$ through vermicompost $+50 \%$ NPK through fertilizers, $75 \% \mathrm{~N}$ through vermicompost + 25\% NPK through fertilizers and absolute control. The Recommended dose of fertilizer was $120 \mathrm{~kg} \mathrm{~N}, 60 \mathrm{P}_{2} \mathrm{O}_{5}$ and $40 \mathrm{~kg} \mathrm{~K}_{2} \mathrm{O}$ per hectare. Rice "Pusa Sugandha 1" seedling was transplanted in first week of July with 2 to 3 seedlings/hill of 21 day of age at spacing of $20 \mathrm{~cm} \times 20 \mathrm{~cm}$. Rice was irrigated frequently to maintain $2-3 \mathrm{~cm}$ standing water in all the plots. The irrigation was stopped 10 days before harvesting of crop. All the recommended package of practices was followed to raise the crop. The crop was harvested during first week of November, 2016. 


\section{Results and Discussion}

\section{Yield attributes and yield}

The results (Table 1) revealed that yield attributes viz., number of effective tillers/hill, length of panicle, number of grains/panicle, number of filled grains/panicle, number of unfilled grains/panicle, test weight and grain yield, straw yield and harvest index of rice influenced significantly by the nutrient management treatments.

\section{Number of effective tillers/hill}

Application of $100 \%$ NPK through fertilizers recorded significantly highest number of effective tillers/hill (9.89) which was at par with $50 \% \mathrm{~N}$ through vermicompost $+50 \%$ NPK through fertilizers and 75\% $\mathrm{N}$ through vermicompost $+25 \%$ NPK through fertilizers as compared to $100 \% \quad \mathrm{~N}$ through vermicompost, $\quad 75 \% \quad \mathrm{~N}$ through vermicompost, farmers practice N:60, P:30 through fertilizers + FYM 3 tonne/ha and absolute control. Application of $100 \%$ NPK through fertilizers increases number of effective tillers/hill to the tune of 17.81 , 20.31, 34.92 and 102.24 per cent over $100 \%$ $\mathrm{N}$ through vermicompost, $75 \% \mathrm{~N}$ through vermicompost, farmers practice $\mathrm{N}: 60, \mathrm{P}: 30$ through fertilizers + FYM 3 tonne/ha and absolute control, respectively.

\section{Length of panicle}

Application of $100 \%$ NPK through fertilizers recorded significantly highest length of panicle $(30.4 \mathrm{~cm})$ over $100 \% \mathrm{~N}$ through vermicompost, $\quad 75 \% \quad \mathrm{~N}$ through vermicompost, farmers practice $\mathrm{N}: 60, \mathrm{P}: 30$ through fertilizers + FYM 3 tonne/ha, $50 \% \mathrm{~N}$ through vermicompost $+50 \%$ NPK through fertilizers, $75 \% \mathrm{~N}$ through vermicompost + 25\% NPK through fertilizers, and absolute control. Percentage increase in length of panicle to the tune of $11.50,13.91,11.93$, $6.82,5.51,24.49$ over $100 \% \mathrm{~N}$ through vermicompost, $\quad 75 \% \quad \mathrm{~N}$ through vermicompost, farmers practice N:60, P:30 through fertilizers + FYM 3 tonne/ha, $50 \% \mathrm{~N}$ through vermicompost $+50 \%$ NPK through fertilizers, $75 \% \mathrm{~N}$ through vermicompost + 25\% NPK through fertilizers and absolute control, respectively.

\section{Number of grains/panicle}

Maximum number of grains/ panicle (73.00) were recorded by application of $100 \%$ NPK through fertilizers which was at par with $50 \%$ $\mathrm{N}$ through vermicompost $+50 \%$ NPK through fertilizers, $75 \% \mathrm{~N}$ through vermicompost + $25 \%$ NPK through fertilizers, $100 \% \mathrm{~N}$ through vermicompost, $75 \% \quad \mathrm{~N}$ through vermicompost as compared to farmers practice N:60, P:30 through fertilizers + FYM 3 tonne/ha and absolute control. Application of $100 \%$ NPK through fertilizers increases number of grains/ panicle to the tune of 4.82 and 15.26 over to farmers practice $\mathrm{N}: 60, \mathrm{P}: 30$ through fertilizers + FYM 3 tonne/ha and absolute control, respectively.

\section{Number of filled/unfilled grains/panicle}

Application of $100 \%$ NPK through fertilizers recorded significantly highest number of filled grains/panicle which was at par with $50 \% \mathrm{~N}$ through vermicompost $+50 \% \mathrm{NPK}$ through fertilizers and $75 \% \mathrm{~N}$ through vermicompost $+25 \%$ NPK through fertilizers as compared to $100 \% \quad \mathrm{~N}$ through vermicompost, $\quad 75 \% \quad \mathrm{~N}$ through vermicompost, farmers practice N:60, P:30 through fertilizers + FYM 3 tonne/ha and absolute control. Whereas, lowest number of unfilled grains/panicle recorded by application of $100 \%$ NPK through fertilizers and absolute control have highest unfilled grains. 
Table.1 Effect of nutrient management on yield attributes and yields of rice

\begin{tabular}{|c|c|c|c|c|c|c|c|c|c|}
\hline Treatments & $\begin{array}{c}\text { Effective } \\
\text { tillers/ } \\
\text { hill }\end{array}$ & $\begin{array}{l}\text { Length } \\
\text { of } \\
\text { panicle } \\
(\mathrm{cm})\end{array}$ & $\begin{array}{l}\text { Grains/ } \\
\text { panicle }\end{array}$ & $\begin{array}{c}\text { Filled } \\
\text { grains/p } \\
\text { anicle }\end{array}$ & $\begin{array}{c}\text { Unfilled } \\
\text { grains/ } \\
\text { panicle }\end{array}$ & $\begin{array}{c}\text { Test } \\
\text { weight } \\
\text { (g) }\end{array}$ & $\begin{array}{c}\text { Grain } \\
\text { yield } \\
\text { (kg/ha) }\end{array}$ & $\begin{array}{c}\text { Straw } \\
\text { yield } \\
\text { (kg/ha) }\end{array}$ & $\begin{array}{c}\text { Harvest } \\
\text { index } \\
\text { (per cent) }\end{array}$ \\
\hline $100 \% \mathrm{~N}$ through vermicompost & 8.44 & 26.94 & 71.00 & 59.67 & 11.33 & 22.20 & 2898 & 5020 & 36.6 \\
\hline $75 \% \mathrm{~N}$ through vermicompost & 8.22 & 26.37 & 70.33 & 58.67 & 11.67 & 21.80 & 2506 & 4699 & 34.7 \\
\hline $100 \%$ NPK through fertilizers & 9.89 & 30.04 & 73.00 & 63.33 & 9.67 & 22.57 & 3233 & 5411 & 37.4 \\
\hline $\begin{array}{l}\text { Farmers practice N:60, P:30 through } \\
\text { fertilizers + } 3 \text { tonne FYM/ha }\end{array}$ & 7.33 & 25.69 & 70.00 & 58.33 & 12.00 & 21.50 & 1632 & 3436 & 32.2 \\
\hline $\begin{array}{l}50 \% \mathrm{~N} \text { through vermicompost }+\mathbf{5 0 \%} \mathrm{NPK} \\
\text { through fertilizers }\end{array}$ & 9.44 & 28.46 & 72.33 & 62.33 & 10.00 & 22.43 & 3110 & 5272 & 37.1 \\
\hline $\begin{array}{l}75 \% \mathrm{~N} \text { through vermicompost }+25 \% \mathrm{NPK} \\
\text { through fertilizers }\end{array}$ & 9.22 & 28.12 & 71.33 & 60.67 & 10.67 & 22.27 & 3045 & 5229 & 36.8 \\
\hline Absolute control & 4.89 & 24.13 & 63.33 & 50.33 & 13.00 & 20.00 & 1106 & 2544 & 30.03 \\
\hline SEm \pm & 0.30 & 0.41 & 0.96 & 1.24 & 1.08 & 0.70 & 59.41 & 51.16 & 1.07 \\
\hline CD at $5 \%$ & 0.94 & 1.26 & 2.97 & 3.84 & 3.19 & 2.17 & 183.17 & 159.40 & 3.31 \\
\hline
\end{tabular}

Table.2 Effect of nutrient management on economics of rice

\begin{tabular}{|c|c|c|c|c|}
\hline Treatments & $\begin{array}{c}\text { Cost of } \\
\text { cultivation } \\
(₹ / h a)\end{array}$ & $\begin{array}{l}\text { Gross } \\
\text { returns } \\
\text { (₹/ha) }\end{array}$ & $\begin{array}{l}\text { Net returns } \\
(₹ / h a)\end{array}$ & B: C ratio \\
\hline $100 \% \mathrm{~N}$ through vermicompost & 41915 & 90956 & 49041 & 2.17 \\
\hline $75 \% \mathrm{~N}$ through vermicompost & 38915 & 78939 & 40024 & 2.03 \\
\hline $100 \%$ NPK through fertilizers & 32570 & 101319 & 68749 & 3.11 \\
\hline Farmers practice N:60, P:30 through fertilizers + 3 tonne FYM/ha & 34057 & 51709 & 17652 & 1.52 \\
\hline $50 \% \mathrm{~N}$ through vermicompost $+\mathbf{5 0 \%}$ NPK through fertilizers & 37842 & 97518 & 59676 & 2.58 \\
\hline $75 \% \mathrm{~N}$ through vermicompost $+25 \%$ NPK through fertilizers & 39878 & 95533 & 55655 & 2.40 \\
\hline Absolute control & 29915 & 35215 & 5300 & 1.18 \\
\hline
\end{tabular}




\section{Test weight (g)}

Application of $100 \%$ NPK through fertilizers recorded significantly highest test weight $(22.57 \mathrm{~g})$ over absolute control but it was nearby $50 \% \mathrm{~N}$ through vermicompost $+50 \%$ NPK through fertilizers, $75 \% \mathrm{~N}$ through vermicompost $+25 \%$ NPK through fertilizers $100 \% \mathrm{~N}$ through vermicompost, $75 \% \mathrm{~N}$ through vermicompost, farmers practice N:60, P:30 through fertilizers + FYM 3 tonne/ha.

\section{Yield}

Results (Table 1) revealed that highest grain (2233 kg/ha) and straw (5411 kg/ha) yield were attained by application of $100 \%$ NPK through fertilizers which was at par with $50 \%$ $\mathrm{N}$ through vermicompost $+50 \%$ NPK through fertilizers over $100 \% \quad \mathrm{~N}$ through vermicompost, $\quad 75 \% \quad \mathrm{~N}$ through vermicompost, farmers practice $\mathrm{N}: 60, \mathrm{P}: 30$ through fertilizers + FYM 3 tonne/ha, $75 \% \mathrm{~N}$ through vermicompost $+25 \%$ NPK through fertilizers and absolute control. The percentage increase in grain yield (11.55, 29.01, 98.10, 06.74 and 92.31) and straw yield $(77.88,15.15,57.47,03.48$ and 12.69) over $100 \% \mathrm{~N}$ through vermicompost, $75 \% \mathrm{~N}$ through vermicompost, farmers practice $\mathrm{N}$ : 60, P: 30 through fertilizers + FYM 3 tonne/ha, $75 \% \mathrm{~N}$ through vermicompost + 25\% NPK through fertilizers and absolute control, respectively.

All the yield attributes and yield were higher with $100 \%$ NPK through fertilizers due slow release and continuous supply of nutrients in balance quantity throughout the various growth stages enables the rice plants to assimilate sufficient photosynthetic products and thus, increased the dry matter and source capacity resulted in increased of yield attributes and finally yields of grain and straw. The results showed that application vermicompost was not helpful in increasing yield attributes and yield of rice. This might be due to its inability to supply nutrients as per demand of rice because of its slow release particularly at the early growth and development stages.

\section{Harvest index}

Application of $100 \%$ NPK through fertilizers recorded significantly highest harvest index (37.4 per cent) which was on par with $50 \% \mathrm{~N}$ through vermicompost $+50 \%$ NPK through fertilizers, $75 \% \mathrm{~N}$ through vermicompost + $25 \%$ NPK through fertilizers, $100 \% \mathrm{~N}$ through vermicompost, $75 \% \quad \mathrm{~N}$ through vermicompost as compared to farmers practice N:60, P:30 through fertilizers + FYM 3 tonne/ha and absolute control.

\section{Economics}

Highest (Table 2) net returns (68749₹/ha) and $\mathrm{B}: \mathrm{C}$ ratio (3.11) were recorded with application of $100 \%$ NPK through fertilizers as compared to $50 \% \mathrm{~N}$ through vermicompost $+50 \%$ NPK through fertilizers, $50 \% \mathrm{~N}$ through vermicompost $+25 \%$ NPK through fertilizers, $100 \% \mathrm{~N}$ through vermicompost, $75 \% \mathrm{~N}$ through vermicompost, farmers practice N:60, P:30 through fertilizers + FYM 3 tonne/ha and absolute control.

In conclusion on the basis of present experiment, it may be concluded that application of $100 \%$ NPK through fertilizers overall better than other treatments. It gives higher values of yield attributes and yield net returns (68749₹/ha) and B:C ratio (3.11) of rice.

\section{References}

Blackman, V.H. 1919. The compound interest law and plant growth. Annals of Botany, 33: $353-360$.

Enyi, B. A. I. 1962. Annals of Botany, 26: 467487. 
GOI (2019) Pocket Book of Agricultural Statistics 2019, Ministry of agriculture \& Farmers Welfare Department of agriculture, cooperation \& Farmers Welfare Directorate of Economics \& Statistics New Delh.

Iqbal, M. T. 2004. Yield and Biomass in Rice Interactions of Nitrogen, Phosphorous and Water Application. Pakistan Journal of Biological Sciences, 7 (12): 2115-20.

John, P.S., George, M. and Jacob, R.Z. 2001. Nutrient mining in agro-climatic zones of Kerala, Fertilizer News, 46:45-52 and 55-57.

Krishnan, B., Ramakrishnan, B., Raja Reddy, K. and Reddy, V. R. 2011. High temperature effect on growth, yield and grain quality. Adv. Agron., 111:89-144.

Metson, A. I. (1956) Method of chemical analysis for survey samples. Bulletin No. 2 Department Science. Mediterranean Research soil Bureau 12.

Olsen, S.R., Cole, C.V., Watnabe, F.S. and Dean, L A. (1954) Estimation of available phosphorus in soils by extraction with sodium bicarbonate. USDA. Circular, 939: 18.

Prasad, B., Prasad, J., and Prasad, R. 1995. Nutrient management for sustained rice and wheat production in calcareous soil amended with green manures, organic manure and zinc. Fertilizers News, 40 (3):39-41.

Singh, D. and Kumar, A. 2014. Effect of sources of nitrogen on growth, yield and uptake of nutrient in rice. Annals of Plant and Soil Research, 16(4): 359-361.
Subbiah, B.V. and Asija, G.L. 1956. A rapid procedure for the estimation of available nitrogen in soils. Current Science, 25: 259-260.

Talashilkar, S.C., Bhangarath, P.P. and Mehta, V.B. 1999. Changes in chemical properties during composting of organic residues as influenced by earthworm activity. Journal of the Indian Society of Soil Science, 47(2): 50-53.

Wang, G. H., Dobermann, A., Witt, C., Sun, Q. Z., and Fu, R. X. 2001. Performance of Site-Specific Nutrient Management for Irrigated Rice in Southeast China. Agronomy Journal, 93(4): 869-78.

Watson, D.J. 1952. The physiological basis of variation in yield. Advances in Agronomy. 6: 103-109.

Williams, R.F. 1946. The physiology of plant growth with special reference to the concept of net assimilation rate. Annals of Botany, Volume 10, Issue 1, Pages 41-72.

Yadav, L., and Meena .N. 2014. Performance of aromatic rice (Oriza sitiva) genotype as influenced by integrated nitrogen management. Indian Journal of Agronomy, 59(2): 51-255.

Zhang, F. S., Cui, Z. L., Chen, X. P., Ju, X. T., Shen, J. B., Chen, Q., Liu, X. J., Zhang, W. F., Mi, G. H., Fan, M. S., and Jiang, R. F. 2012. "Integrated Nutrient Management for Food Security and Environmental Quality in China." Advances in Agronomy, 116: 1-40.

\section{How to cite this article:}

Vishnu, Vishal Verma, Gabu Singh Gathiye Anil Kumar and Shri Rakesh. 2020. Response of Integrated Nutrient Management on Yield and Economics of Rice (Oryza sativa L.). Int.J.Curr.Microbiol.App.Sci. 9(09): 793-798. doi: https://doi.org/10.20546/ijcmas.2020.909.100 